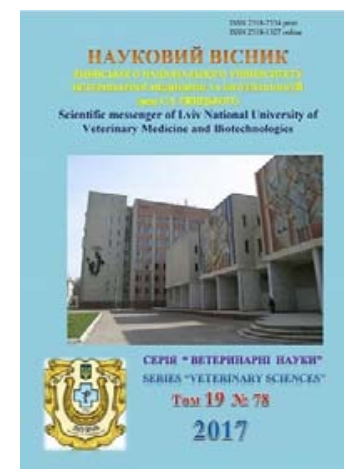

Науковий вісник Львівського національного університету ветеринарної медицини та біотехнологій імені С.З. Гжицького

Scientific Messenger of Lviv National University of Veterinary Medicine and Biotechnologies

doi:10.15421/nvlvet7825

ISSN 2518-7554 print

ISSN 2518-1327 online

http://nvlvet.com.ua/

УДК 636.22/.28:612.6:619:618.2/.7

\title{
Ритмічність статевих циклів корів та рівень прихованої ранньої ембріопатії
}

\author{
С.О. Сідашова, О.Г. Гуменний \\ fly1978@mail.ru \\ Одеський державний аграрний університет, \\ вул. Пантелеймонівська, 13, м. Одеса, 65012, Украӥна
}

\begin{abstract}
Подано результати моніторингу ритмічності статевих ииклів корів між повторними осіменіннями. Достовірно доведено, ще в умовах безприв'язного утримання корів комплексу промислового типу значно поширена неритмічність статевих ииклів після шттучного осіменіння, щцо не закінчилось тільністю (за результатами УЗД через 35-45 днів), причому помітно суттєвий вплив сезонно-кормових факторів. Лише в 7,58-22,70\% спостережень (відповідно, зима-літо) відмічали статеві ичикли фізіологічної тривалості; скорочені статеві ичикли фіксували в 3,03-10,75\%, а подовжені - в 89,39-65,95\%, відповідно. Середній інтервал між повторними циклами після неефективного осіменіння складав в зимовий сезон 70,41 дня, а в літній - 38,54 дня, щчо опосередковано свідчило про наявність у корів прихованої ембріональної смертності. Аналіз комплексу етологічних і морфо функціональних показників дійного стада достовірно виявив критичний інтервал прихованої ранньої ембріопатії в період від імплантаиії зародку до початку формування плідних оболонок (24-63 дні між повторними осіменіннями), що свідчило про необхідність подальшого вивчення чинників, які негативно впливають на приживленість ембріонів у лактуючих корів в умовах промислових технологій експлуатації. УЗ-скануванням у дослідних корів не виявлено запальних процесів в порожнині матки, але діагностовано 73\% випадків дегенеративно-дистрофічних ушкоджень яєчників, щзо свідчило про необхідність застосування гісто- і цитологічних методів дослідження для вивчення деструктивних процесів в будові тканин репродуктивного тракту.
\end{abstract}

Ключові слова: корови, статевий ичилл, итучне осіменіння, тільність, рання ембріопатія, імплантація, ембріони, яєчники, гонадопатії, УЗД, слизові оболонки.

\section{Ритмичность половых циклов коров и уровень скрытой ранней эмбриопатии}

\author{
С.О. Сидашова, О.Г. Гуменный \\ fly1978@mail.ru
}

Одесский государственный аграрный университет, ул. Пантелеймоновская, 13, г. Одесса, 65012, Украина

\begin{abstract}
Поданы результаты мониторингового исследования ритмичности половых ииклов коров между повторными осеменениями. Достоверно установлено, что в условиях беспривязного содержания коров в промышленном молочном комплексе значительно распространена неритмичность половой циклики коров после осеменений, не закончивщихся стельностью (по результатам УЗИ через 35-45 дней). При этом отмечено существенное влияние сезонно-кормовых факторов: продолжительность интервалов между осеменениями зимой составляла в среднем 70,41 дней, а летом 38,54 дней, соответственно, что свидетельствовало о наличии скрытой ранней эмбриопатии у коров. Только в 7,58 и 22,70\% (зима-лето) наблюдений был установлен интервал между повторными осеменениями в пределах видовой физиологической нормы, укороченные иикль фиксировали в 3,03-10,75\% коров, удлиненные - у 89,39-65,95\%, соответственно. Анализ комплекса этологических и морфофункииональных показателей дойного стада достоверно выявил критический интервал скрытой эмбриональной
\end{abstract}

Citation:

Sidashova, S.O., Gumenny, O.G. (2017). Rhythm of sexual cycles of cows and level of the hidden early embrionic mortality. Scientific Messenger LNUVMB, 19(78), 121-128. 
смертности в период между имплантаиией зародыми и формированием плодовых оболочек (40-63 дня между повторными осеменениями). УЗ - сканированием у коров не установлено воспалительньх процессов в полости матки, но диагностировано 73\% случаев дегенеративно - дистрофических повреждений яичников, что показывает необходимость использования гисто- и цитологических методов исследований для изучения возможных деструктивных прочессов в строении клеток и тканей репродуктивного тракта.

Ключевые слова: коровы, половой цикл, искусственное осеменение, стельность, ранняя эмбриопатия, эмбрионы, яичники, гонадопатии, УЗИ, слизистье оболочки.

\title{
Rhythm of sexual cycles of cows and level of the hidden early embrionic mortality
}

\author{
S.O. Sidashova, O.G. Gumenny \\ fly1978@mail.ru \\ Odessa State Agrarian University, \\ Panteleimonovska Str., 3, Odessa 65012, Ukraine
}

\begin{abstract}
Results of a monitoring research of rhythm of sexual cycles of cows between repeated inseminations are presented. It is authentically established that in the conditions of loose housing keeping of cows the unevenness of a sexual cycles of cows after the inseminations which did not end with stylishness is considerably widespread in the production lactic complex (by results of ultrasonography in 35-45 days). At the same time the significant influence of seasonal and fodder factors is noted: duration of intervals between inseminations averaged 70.41 days in the winter, and in the summer of 38.54 days, respectively, that demonstrated presence of the hidden early embryonic mortality at cows. Only in 7.58 and $22.70 \%$ (winter-summer) of observations the interval between repeated inseminations within specific physiological norm was established, the shortened cycles fixed at 3.03-10.75\% of cows, extended - at 89.39-65.95\%, respectively. The analysis of a complex ethological and the morph functional of indexes of dairy herd authentically revealed a critical interval of the hidden fetal mortality of the period between implantation of a nucleus and formation of fruit envelopes (40-63 days between repeated inseminations). Ultrasonography by scanning at cows it is not established inflammatory processes in a cavity of the uterus, but 73\% of cases degenerately - dystrophic damages of ovaries are diagnosed that shows need of use gisto- and cytological methods of researches for studying of possible destructive processes in structure of the cells and fabrics of a reproductive path.
\end{abstract} cosa's.

Key words: cows, sexual cycle, simulated insemination, stylishness, early fetal mortality, embryos, ovaries, ultrasonography, mu-

\section{Вступ}

Відтворення дійного стада обумовлюється особливостями статевої функції корів, які є поліциклічними тваринами з виразною періодичністю змін поведінки, стану геніталій і характеру обміну речовин протягом статевого циклу. Фізіологічною нормою довжини статевого циклу корів у сучасних молочних порід визнано 19-21 день в середньому (Kastelic, 1991; Iablonskyi, 2011; Melnyk and Sidashova, 2013; Buhrov et al., 2013; Buhrov and Khmelkov, 2014; Buhrov, 2014; Embroze, 2015). За даними ряду авторів зустрічаються індивідуальні коливання від 16 до 26 діб (Melnyk and Sidashova, 2013; Buhrov, 2014). Але в літературі вказується, що повторний еструс у корови більше ніж 24 дні від осіменіння може свідчити про ймовірність загибелі ембріона після 16 дня розвитку (Kastelic, 1991; Shilina et al., 2008; Iablonskyi, 2011; Buhrov and Khmelkov, 2014; Embroze, 2015). Зародок, що гине на ранніх стадіях розвитку, звичайно розсмоктується без зовнішніх клінічних ознак, тому ембріональна смертність залишається непоміченою, при загибелі ембріону вже на стадії імплантації - можливе виявлення подовженого інтервалу до настання наступного статевого збудження корови.

Ембріональна смертність в молочному скотарстві відноситься до основних факторів економічних втрат, але нині визначити іï рівень доволі проблематично. В літературі наводяться розбіжні визначення поняття, що характеризує ембріопатію за різними методични- ми підходами дослідження поголів'я, неоднозначна періодизація термінів ембріональної смертності (Iablonskyi, 2011; Melnyk and Sidashova, 2013; Buhrov and Khmelkov, 2014; Embroze, 2015). Так, за даними О.Д. Бугрова зі співавторами (2011), що дослідили під час експериментального нехірургічного вимивання вміст порожнини матки корів після 7-8 дня від осіменіння, було виявлено 100-84\% запліднених зигот, а ембріональні втрати складали 15,38-30,00\% (Buhrov and Khmelkov, 2014). Зарубіжні автори реєстрували через 34 дні після овуляції тільки 23\% живих зародків (Iablonskyi, 2011). Часто зустрічаються в літературі повідомлення, що низька заплідненість корів від першого осіменіння в 15-40\% випадків може бути пояснена ранньою ембріональною смертністю (Kastelic, 1991; Iablonskyi, 2011).

Більшість авторів згодні з думкою, що подовжені інтервали між повторними осіменіннями корів свідчать про наявність ранньої ембріональної смертності, але наводяться дані, що збільшення тривалості статевого циклу обумовлене насамперед пропусками стадій збудження у корів при недосконалій організації вибірки тварин (Buhrov et al., 2013; Buhrov, 2014). Зважаючи на статистичні дані щодо фактичної тільності при штучному осіменінні корів не вище ніж 4045\%, можна припустити факт найбільших пренатальних втрат на етапі доімплантаційного / імплантаційного періодів, протягом яких проходять важливі фізіологічні та морфологічні зміни тканин репродуктивних органів, які ще недостатньо вивчені. 
Метою нашого дослідження було виявлення закономірностей ритмічності у тривалості статевих циклів після штучного осіменіння корів і встановлення чинників, які провокують подовження інтервалу між двома осіменіннями.

Для виконання мети нами було поставлено і здійснено ряд завдань, а саме:

- проведено спостереження за поведінкою стада i проявом статевих рефлексів у безприв'язному утриманні дійних корів протягом зимового, весняного i літнього сезонів;

- проведено аналіз тривалості інтервалів між повторними осіменіннями за даними зоотехнічного обліку;

- здійснено дослідження стану репродуктивних органів дослідних корів 3 допомогою УЗ-сканера;

- проведено співставлення даних, отриманих різними способами і кореляції між ними.

\section{Матеріал та методи досліджень}

Експериментальну частину роботи проводили на дослідній базі молочного комплексу, що входив у склад агропромислових формувань Одеської області. Організаційну структуру проведення науково- виробничого дослідження показано в таблиці 1, методологію моніторингу статевої циклічності дійного поголів'я - на схемі 1.

Всі дані обстеження поголів'я структурували за принципом «мале стадо» на два періоди: зимововесняний (листопад-грудень 2016 р. - січеньберезень 2017 р.) і весняно-літній (квітень-липень 2017 р.), технологічною межею став квітень - перехід на літній раціон з поступово зростаючим внесенням сезонної зеленої маси. Умови утримання, доїння, графік візуального спостереження за поведінкою корів і технологія ШО були аналогічні протягом року. Дані моніторингу ритмічності повторних статевих циклів було структуровано відповідно до критичних періодів, експериментально визначених і викладених в літературних джерелах (Humblot, 2001; Havrylenko and Sharapa, 2009; Iablonskyi, 2011; Melnyk and Sidashova, 2013; Buhrov and Khmelkov, 2014), виходячи 3 чого робився висновок про наявність ранньої ембріопатії у корів при подовженні інтервалу між повторними осіменіннями понад фізіологічну норму, разом $з$ впливом інших екзогенних чинників як складової цього терміну. Умовний рівень цієї складової і було визначено.

\section{Структура науково-виробничого дослідження}

Табличяя 1

\begin{tabular}{|c|c|}
\hline Умови дослідження & Характеристика виробничих процесів і методів дослідів \\
\hline Дослідне поголів’я & $\begin{array}{l}\text { Дійні корови 1-6 лактації УЧМ породи, заводської вгодованості (середня молочна } \\
\text { продуктивність } 5000 \text { кг за лактацію); середнє річне поголів'я } 650 \text { корів }\end{array}$ \\
\hline $\begin{array}{l}\text { Період дослідного моніторингу } \\
\text { стада }\end{array}$ & Зимово-весняний і весняно-літній сезони 2016-2017рр. \\
\hline $\begin{array}{l}\text { Умови утримання і } \\
\text { експлуатації }\end{array}$ & $\begin{array}{l}\text { Молочний комплекс промислового типу з відкритими приміщеннями (ангари). } \\
\text { Безприв'язні секції на 80-120 корів. } \\
\text { 2-х кратне доїння в доїльному залі. } \\
\text { Щоденний однотипний раціон (монокорм) з внесенням сезонної зеленої маси (зелений } \\
\text { конвеєр). }\end{array}$ \\
\hline $\begin{array}{c}\text { Оптимізація кормової } \\
\text { програми і біозахист поголів’я }\end{array}$ & $\begin{array}{l}\text { Введення в щоденний раціон з березня по травень кормового препарату «Агробіобак- } \\
1 » 3 \text { симбіотичними культурами лакто- і біфідобактерій в дозуванні відповідно до } \\
\text { настанови виробника (Donchenko, 2013) }\end{array}$ \\
\hline $\begin{array}{l}\text { Режим ШО корів і контроль } \\
\text { заплідненості }\end{array}$ & $\begin{array}{l}\text { Двократне виявлення в секціях (без биків-пробників). } \\
\text { Однократне ШО ректо-цервікальним способом. } \\
\text { Імпортна спермопродукція биків червоно-рябої голштинської породи (виробництво: } \\
\text { США, Канада). } \\
\text { Контроль тільності - через 35-45 днів УзД. }\end{array}$ \\
\hline $\begin{array}{l}\text { Облік показників продуктив- } \\
\text { ності і відтворення стада }\end{array}$ & $\begin{array}{l}\text { Комп’ютерна база обліку Dairy Plan. } \\
\text { Журнал штучного осіменіння корів (форма № } 10 \text { - мол). }\end{array}$ \\
\hline $\begin{array}{l}\text { Показники - індикатори стану } \\
\text { статевої функції корів }\end{array}$ & $\begin{array}{l}\text { Зоотехнічні: інтервали між повторними осіменіннями. } \\
\text { УзД: морфологія нормального стану матки, патоморфологія матки (приховані та } \\
\text { серозно-гнійні хронічні ендометрити); морфофункціональний стан яєчників (фоліку- } \\
\text { лярна або лютеїнова фаза); гонадопатії (гіпотрофія / гіпоплазія яєчників, фолікулярна } \\
\text { кістозність, лютеїнові кісти). }\end{array}$ \\
\hline Методи дослідження & $\begin{array}{l}\text { Загальні: статистичний, порівняльний, структурно-функціональний. } \\
\text { Спеціальні: диференціальна УЗ-діагностика; вагінальний огляд слизових корів; спо- } \\
\text { стереження за поведінкою корів (фіксація прояву статевих рефлексів). }\end{array}$ \\
\hline
\end{tabular}

Всі біотехнологічні процедури проводили в умовах виробничих приміщень, для фіксації тварин задіяли станки для ветеринарних процедур. У ході дослідів здоров'ю тварин не було завдано шкоди (Melnyk and Sidashova, 2013; Buhrov, 2014; Sidashova and Halak, 2016). Все поголів'я дослідного підприємства було забезпечено плановими протиепізоотичними захода- ми і вакцинаціями проти інфекційних хвороб відповідно до чинних ветеринарних вимог.

Результати досліджень були підсумовані та подані в таблицях і діаграмах. Отримані дані були обраховані згідно з програмою IBM Statistics - 2011 (Version 20) 3 обчисленням стандартних статистичних показників (Sidashova and Halak, 2016; Sidashova et al., 2016). 


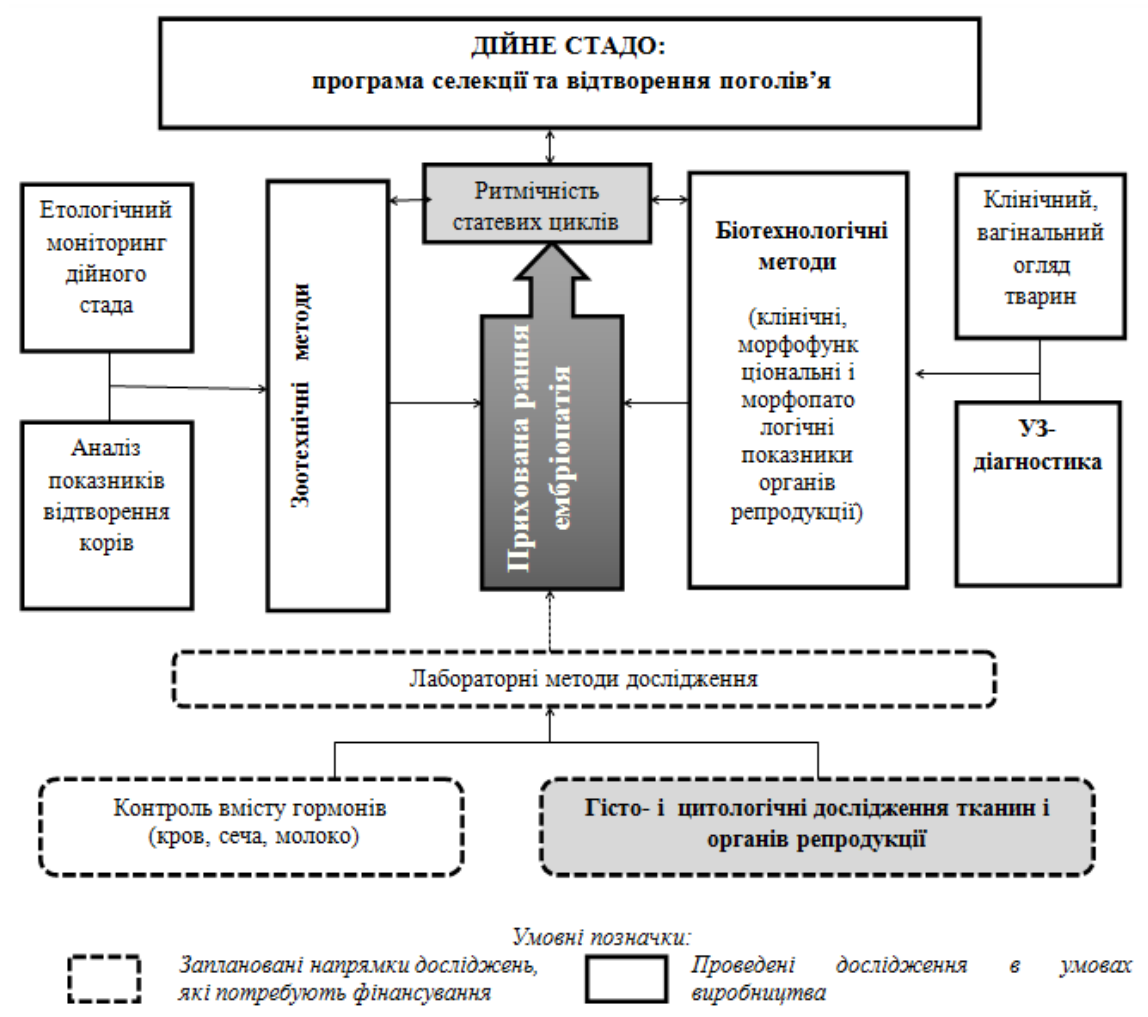

\section{Рис. 1. Методичний підхід до вивчення ритмічності статевих циклів та рівня прихованої ранньої ембріопатії у корів в умовах промислових молочних комплексів}

\section{Результати та їх обговорення}

Результати моніторингу за тривалістю 317 циклів корів після штучного осіменіння, яке не закінчилось тільністю, наведені в таблиці 2. Як показують протягом року дані, в стаді після осіменіння спостерігали цикли 3 фізіологічним інтервалом в середньому 21 день, але в зимовий сезон їх суттєво і достовірно менше, ніж в теплий (відповідно 7,58 і 22,70\%). Скоро- чених інтервалів 9-11 днів влітку було достовірно більше, ніж взимку (відповідно 3,03 і 11,3\%). Структура інтервалів дослідженого поголів'я суттєво відрізнялась від даних, наведених в інших дослідах, що характеризувало вплив екзогенних факторів та методики спостережень на показник, який вивчався (Kastelic, 1991; Buhrov et al., 2013; Buhrov and Khmelkov, 2014).

Структура інтервалів між повторними циклами у корів після неефективного осіменіння

\begin{tabular}{|c|c|c|c|c|c|c|c|c|}
\hline \multirow{3}{*}{$\begin{array}{c}\text { Інтервал між } \\
\text { повторними } \\
\text { ШО, днів }\end{array}$} & \multicolumn{8}{|c|}{ Періоди моніторингу } \\
\hline & \multicolumn{2}{|c|}{ Зима - весна } & \multicolumn{3}{|c|}{ Весна - літо } & Зима -весна & Весна - літо & $\pm \mathrm{m}$ \\
\hline & циклів & $\%$ & циклів & $\%$ & $\pm \mathrm{m}$ & \multicolumn{3}{|c|}{ Середній інтервал, дн. } \\
\hline$\leq 15$ & 4 & 3,03 & 21 & 11,35 & 5,25 & 10,75 & 9,19 & 0,85 \\
\hline $16-23$ & 10 & 7,58 & 42 & 22,70 & 4,20 & 20,90 & 20,57 & 0,98 \\
\hline $24-39$ & 16 & 12,12 & 49 & 26,49 & 3,06 & 29,25 & 30,65 & 1,05 \\
\hline $40-63$ & 29 & 21,97 & 45 & 24,32 & 1,55 & 49,45 & 49,58 & 1,00 \\
\hline $64-89$ & 25 & 19,94 & 20 & 10,81 & 0,30 & 76,56 & 75,20 & 0,98 \\
\hline$\geq 90$ & 48 & 36,36 & 8 & 4,32 & 0,17 & 108,88 & 103,25 & 0,95 \\
\hline Разом & $132^{\mathrm{a}}$ & 100 & $185^{\mathrm{b}}$ & 100 & 1,40 & $70,41^{\mathrm{c}}$ & $38,54^{d}$ & 0,55 \\
\hline
\end{tabular}

Прим.: $(a-b) P<0.01$, при $r=-0,432 ;(c-d) P>0.05$.

Тривалість проміжків між повторними осіменіннями до 24 днів може свідчити про відсутність настання запліднення у корів в зимовий сезон після 10,61\% процедур інсемінації, а в літній $-31,65 \%$. Всі інші інтервали між повторними осіменіннями опосередковано свідчать про загибель зародка, але точний рівень ембріональної смертності контроль подовжених циклів не дає, що підтверджують дослідження інших авторів. Методична інноваційність нашого дослідження полягала в аналізі структурованих даних первинного зоотехнічного обліку, що показано в динаміці діаграм 1 і 2. Незалежно від сезону року тривалість повторних циклів після осіменіння була майже однаковою за періоди критичних днів для розвитку ембріона, що опосередковано свідчило про наявність постійно діючих факторів, які сприяли ранній ембріопатії у дійних корів. 


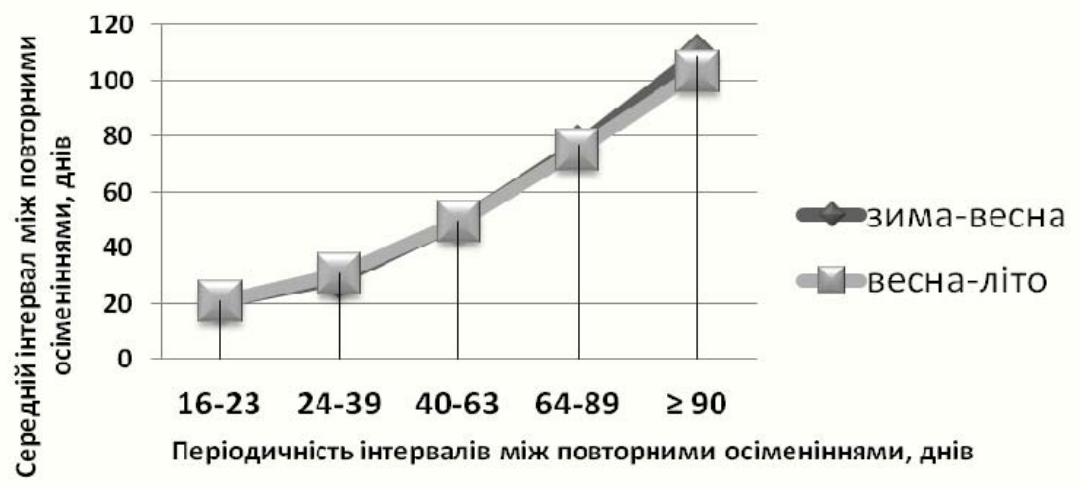

Рис. 1. Тривалість інтервалів між повторними осіменнями корів в різні сезонни $(\mathbf{n}=297)$

Водночас в кількісному співвідношенні числа подовжених циклів аналіз показує достовірну тенденцію до суттєвого впливу сезонних факторів. Збільшення числа корів з повторними циклами через 24-39 днів після осіменіння свідчить про підвищення рівня загибелі доімплантаційних ембріонів в літній період, водночас як суттєве зменшення тривалих термінів між осіменіннями (понад 90 днів) говорить про більшу активність статевої функції корів після втрати попередньої вагітності в ранні строки. Дані ряду авторів пояснюють різке зниження ембріональної виживаності в період формування плаценти корів негативним впливом аліментарних чинників і незбалансованості раціону, особливо високим вмістом концентратів (Humblot, 2001; Iablonskyi, 2011; Reshetnikov, 2014). Плацентація ембріонів при концентратному типі годівлі затримується на 3-5 діб, що викликає несинхронність в стадіальному розвитку зародка і секреторних клітин ендометрію. При згодовуванні значної кількості концентратів дійним коровам у них знижується рН вмісту рубця, наслідком чого стає погіршення всмоктування ЛЖК та зниження біодоступності поживних речовин кормів. В результаті накопичуються істотні відхилення метаболізму організму тварин (зниження рівня глюкози, лужного резерву крові, $\mathrm{pH}$ сечі), а вміст ЛЖК, загальних ліпідів, холестерину та кетонових тіл збільшується, що створює передумови для деструктивних процесів в печінці. Ці процеси негати- вно впливають на функцію яєчників, особливо жовтих тіл, що викликає зменшення розмірів лютеоцитів, висвітлення цитоплазми і утворення жирових вакуолей, розростання сполучної тканини, зменшення кількості капілярів кровоносної мережі. Зміни в структурі жовтих тіл приводять до негативних зрушень в стані слизових оболонок та мускульного шару матки, зменшення числа маточних залоз, розростання сполучної тканини і недорозвиненості судинної системи, а в підсумку - до зниження секреції прогестерону.

Введення в раціон культур симбіотиків (пробіотичний кормовий препарат «Агробіобак-1») дозволило у дослідженого дійного поголів'я змоделювати процеси оптимізації біодоступності поживних речовин кормів, що поліпшило ряд виробничих показників (збільшення вмісту жиру в молоці до 4,4-4,6\% при базовій 3,5\% в квітні, через місяць після вводу кормових пробіотиків). Відповідно помітно зменшився рівень прихованої ембріональної смертності, особливо на стадії плацентації зародка. Число інтервалів понад 64 дні, а особливо понад 90 днів, між повторними осіменіннями суттєво і достовірно знизилось до 10,81 та 4,32\%, відповідно. Наші дані збігаються з висновками інших авторів щодо застосування про біотичних культур для підвищення біологічної цінності кормів (Antipov and Subbotin, 1989; Donchenko, 2013; Sidashova et al., 2016; Sidashova and Humennyi, 2016).
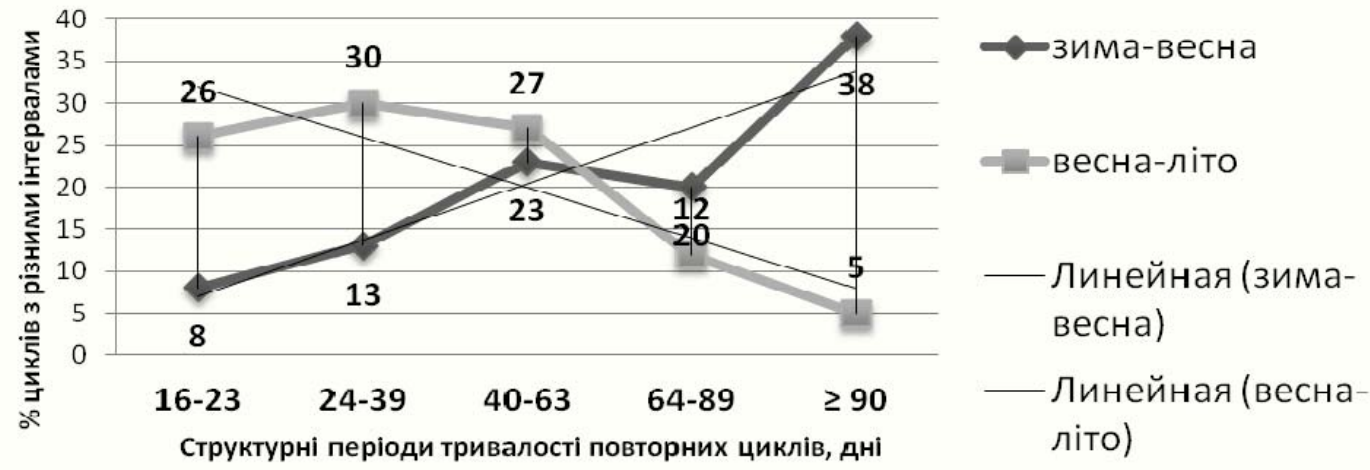

Рис. 2. Структура тривалості інтервалів між попвторними осіменіння корів в різні сезони (n=317 циклів)

Звертає на себе увагу дуже подібне число подовжених циклів (23-27\%) в період від 64 до 89 днів протягом року, що може опосередковано виявляти найбільш критичний термін для зародків в стаді корів дослідженого господарства, а саме стан репродуктивної системи після імплантації ембріона і до формування алантоіса. Вірогідно, це може свідчити про наявність дефектів в структурі або функції ендомет- 
рія матки, але ультразвукове обстеження дослідної групи (83 голови) показало відсутність запальних процесів в порожнині матки (тільки 2 корови, або $2,41 \%$, мали ендометрити прихованої хронічної форми). Ряд дослідників, виходячи з експериментальних даних, вказують на те, що у корів в умовах промислових комплексів та хронічного дисбіозу слизових оболонок розвиваються імпарні хвороби, які мають латентний пожиттєвий характер, коли патогени локалізуються тільки в окремих органах і тканинах, що призводить до повільного пошкодження їх будови (Humennyi and Morozov, 2007; Humennyi, 2016). Таким чином, в ендометрії матки і фолікулярному шарі гонад можуть накопичуватися деструктивні зміни клітин і тканин, які призводять до поступової заміни функціональних тканин сполучною, що суттєво погіршує діяльність органу (Sidashova et al., 2016). Але такі структурні зміни можуть бути виявлені тільки при методичних гісто- та цитологічних дослідженнях тканин органів відтворення.

Дані літератури свідчать про експресію факторів патогенності бактерій, в тому числі умовно патогенних, як адаптивну реакцію на комбіновану дію різноманітних стресів, особливо в техногенно зміненому середовищі, яким є приміщення тваринницького комплексу з високою концентрацією поголів'я (Hill, 1965; Humblot, 2001; Yong et al., 2002; Ran et al., 2003; Shilina et al., 2008; Pryskoka et al., 2010). Для факторів вірулентності, регульованих експресією факторів патогенності, характерні неспецифічна цитотоксичність та супресивна дія на захисні системи організму господаря.

Виходячи з наявних апаратних ресурсів господарства, ми провели деталізоване УЗ-сканування яєчників дослідних корів, які не мали запальних процесів ендометрію за даними ультразвукового обстеження (табл. 3 і 4).

Табличя 3

Результати У3-сканування стану ясчників корів через 35-45 днів після неефективного осіменіння (травень 2017 р.) (тільки корови, у яких діагностовано відсутність запальних процесів в порожнині матки)

\begin{tabular}{|c|c|c|}
\hline \multirow{2}{*}{ Показники } & \multicolumn{2}{|c|}{$\begin{array}{c}\text { Кількість корів, серед } \\
\text { обстежених }\end{array}$} \\
\cline { 2 - 3 } & Гол. & $\%$ \\
\hline Морфофункціональна норма & 25 & 30,86 \\
\hline В т.ч. жовте тіло & 21 & 25,93 \\
\hline Гонадопатії, разом* & 56 & 69,14 \\
\hline Всього обстежено & 81 & 100 \\
\hline
\end{tabular}

Прим.: деталізачія діагнозів патологічних станів яєчників показана в табл. 4.

В цілому серед корів, які не мали вагітності після попереднього осіменіння, лише у $31 \%$ яєчники не мали патологій. У 26\% корів діагностовано функціональне жовте тіло яєчника, що сумарно свідчило, 3 одного боку, про можливість ембріональної загибелі, а 3 іншого - про невиявлені повторні статеві цикли ареактивного характеру.

\section{Структура дисфункцій ясчників в групі корів після неефективного осіменіння}

\begin{tabular}{|c|c|c|}
\hline \multirow[t]{2}{*}{ Показники } & \multicolumn{2}{|c|}{$\begin{array}{c}\text { Кількість корів, } \\
\text { серед всіх } 3 \\
\text { діагнозом гона- } \\
\text { допатія: }\end{array}$} \\
\hline & Гол. & $\%$ \\
\hline $\begin{array}{l}\text { Гіпогонадизм (гіпотрофія / гіпоп- } \\
\text { лазія значно виражена) }\end{array}$ & 6 & 10,71 \\
\hline $\begin{array}{l}\text { Кістозні дегенерації фолікулів } \\
\text { (одиночні кісти і полікістоз) }\end{array}$ & 41 & 73,21 \\
\hline $\begin{array}{l}\text { Гормональна дисфункція яєчників } \\
\text { (одночасно функціональне ЖТ і } \\
\text { фолікулярна кіста) }\end{array}$ & 9 & 16,07 \\
\hline Всього обстежено & 56 & 100 \\
\hline
\end{tabular}

Структура патологій яєчників корів після неефективного запліднення свідчила про наявність суттєвих дегенеративних змін в фолікулярній тканині - 73,21\% випадків фолікулярних одиночних або дрібних множинних кіст. У майже $11 \%$ корів було виявлено значне зниження функції обох яєчників в результаті розвитку дистрофічних процесів у фолікулярному шарі. В 16\% корів встановлено гормональне порушення у вигляді морфологічно активного жовтого тіла, розташованого поряд або контрлатерально з фолікулярними кістами. Звертає увагу факт відсутності лютеїнових кіст в обстеженій групі, що збігається 3 даними інших авторів щодо впливу аліментарних лютеолітичних чинників (Reshetnikov, 2014). УЗ-діагностикою було встановлено, що 69,14\% корів, у яких фіксували подовжені статеві цикли після попереднього штучного осіменіння, мали дисфункцію яєчників, у більшості $(83,92 \%)$ це були дегенеративно-дистрофічні зміни тканин.

Таким чином, комплексне обстеження дійного поголів'я 3 допомогою етологічних, морфологічних, структурно-функціональних методів із залученням аналізу даних зоотехнічного обліку виявило значне поширення серед осіменених корів повторних циклів 3 подовженим інтервалом, тривалість якого коливалася залежно від сезону (взимку - 70,41 днів в середньому, влітку - 38,54 відповідно). Методологія аналізу дозволила виявити найбільш критичні періоди в прихованій ембріональній смертності обстеженого стада, а саме інтервали від 24 до 63 днів після осіменіння, що опосередковано свідчило про постійно діючі негативні фактори, які пошкоджували ранні ембріони на стадії імплантації та початку плацентації. Морфологічне дослідження яєчників підтвердило наявність у досліджених корів дегенеративних і дистрофічних змін в цих ключових органах репродукції, але в умовах господарства не вдалося встановити пошкодження ендометрію матки. Загальновідомо, що хронічні патологічні процеси в тканинах матки і яєчників пов'язані та взаємообумовлені; нервовогуморальні розлади в одному органі провокують порушення гормонального фону всієї репродуктивної системи, а відхилення від нормального стану середовища порожнини матки викликає порушення в живленні зародка та несинхронність процесів імпланта- 
ції, які можуть призвести до його загибелі на більш пізньому етапі плацентації.

Розрахунок оптимізації економічних втрат внаслідок зниження прихованої ранньої ембріопатії у дійних корів за використання сезонно-кормових факmopis

Аналіз комплексу експериментальних даних і виробничих показників дозволив виявити напрямки оптимізації відтворення дійного поголів'я за рахунок скорочення інтервалів неплідності між повторними осіменіннями, а саме: теплий сезон та введення в раціон зелених кормів і симбіотичних мікробних культур. В умовах реального виробництва поки не вдалося виокремити дію кожного з факторів, що потребує більш детальних досліджень.

Для ілюстрації наведемо розрахунок отриманої економії витрат (Lapotko, 2007; Havrylenko and Sharapa, 2009). Виходячи 3 усереднених вихідних даних (вартість 1 кг сирого молока - 7,50 грн, собівартість 1 кормового дня дійної корови - 60 грн, собівартість новонародженого теляти прирівняна до 150 кг молока, недоотримання приплоду за 1 день яловості 0,035 вартості теляти) можна визначити економію при скороченні інтервалу між повторними осіменіннями однієї корови за рахунок зменшення втрат в молочній продуктивності та недоотримання приплоду, а саме: $(60$ грн $\cdot 0,2+39$ грн $) \cdot 31,87$ кормоднів $=1625$ грн

\section{Висновки}

1. Моніторинг дійного стада в умовах безприв'язного утримання промислового комплексу показав суттєве поширення неритмічності статевих циклів корів між повторними осіменіннями при значному впливові сезонно-кормових факторів (зималіто), а саме: статеві цикли фізіологічної тривалості спостерігали в 7,58-22,70\% виявлення еструсу, скорочені цикли - в 3,03-10,75\%, подовжені - в 89,3965,95\% відповідно.

2. В теплий сезон при внесенні в щоденний раціон зеленої маси і про біотичного препарату спостерігали достовірне скорочення протяглості інтервалів між повторними осіменіннями корів, а саме: при зимовому раціоні середній інтервал складав 70,41 дня, а в теплий сезон за переходу на зелений конвеєр відповідно - 38,54 дня.

3. Достовірне встановлення закономірності у 22 і 24\% (зима-літо, відповідно) подовжених статевих циклів між неефективними осіменіннями з інтервалом 40-63 дні опосередковано підтверджує поширення в стаді прихованої ембріональної смертності, що припадає на період початку плацентації, але особливості патогенезу цих процесів потребують додаткових досліджень.

4. Використання сезонно-кормових факторів у комплексі з пробіотичним захистом слизових травного шляху дійного поголів'я дозволило в умовах реального виробництва суттєво зменшити неплідний термін між повторними осіменіннями (на 37,87 дня), в результаті чого отримано оптимізацію виробничих показників.

\section{Бібліографічні посилання}

Antipov, V.A., Subbotin, V.M. (1989). Jeffektivnost' i perspektivy primenenija probiotikov. Veterinarija. 12, 55-58 (in Russian).

Buhrov, O.D., Khmelkov, V.M. (2014). Rannia doimplantatsiina embrionalna smertnist $u$ telyts ta koriv. NTB IT UAAN. Kharkiv. 113, 52-57 (in Ukrainian).

Buhrov, O.D. (2014). Vyiavlennia i vybirka koriv i telyts u statevii okhoti (metodychni rekomendatsii). Kh. (in Ukrainian).

Buhrov, O.D., Shakhova, Yu.Iu., Kryshtal, O.M. (2013), Vplyv intervalu mizh osimeninniamy na vidtvornu zdatnist koriv i telyts. NTB IT NAAN. 113, 58-65 (in Ukrainian).

Havrylenko, M., Sharapa, H. (2009). Eksperymenty shchodo vidtvorennia. Tvarynnytstvo ta veterynariia. 6, 140-144 (in Ukrainian).

Humennyi, O.H. (2016). Metryty koriv v hospodarstvakh Ukrainy. Mater. mizhnarod. konferentsii «Efektyvni veterynarni tekhnolohii». Odesa (in Ukrainian).

Humennyi, O.H., Morozov, M.H. (2007). Formy ta klinichnyi proiav infektsiinoho rynotrakheitu pustuloznoho vulvovahinitu v hospodarstvakh Odeskoi oblasti. Ahrarnyi visnyk Prychornomor"ia: zb. Nauk. Prats ODAU. Odesa. 14(39), 62-65 (in Ukrainian).

Donchenko, D.V. (2013). Povyshenie perevarimosti kormov. Rekomendacii. NP laboratorija «Ukrprolajf», Cherkasy (in Russian).

Embroze, Dzh. (2015). Faktory, shcho vplyvaiut na plidnist koriv. Veterynarna praktyka. 4, 38-46 (in Ukrainian).

Lapotko, A.M. (2007). Jenergojekonomicheskij resurs molochnogo skotovodstva. Belorusskoe sel'skoe hozjajstvo. 9, 120-129 (in Russian).

Melnyk, V.O., Sidashova, S.O. (2013). Akusherstvo, hinekolohiia i biotekhnolohiia vidtvorennia tvaryn. Konspekt lektsii. Mykolaiv (in Ukrainian).

Pryskoka, V.A., Sobko, Yu.A., Panchenko, O.O. (2010). Mikroorhanizmy: zmina spivvidnoshen mizh populiatsiiamy, nadlyshkovyi rist yak peredumova vynyknennia zakhvoriuvan. Veterynarna medytsyna. 9, 30-33 (in Ukrainian).

Reshetnikov, N.M. (2014). Stimuljacija vosproizvoditel'noj funkcii korov i telok: vlijanie kormlenija. Efektivne tvarinnictvo. 2(74), 19-21 (in Russian).

Sidashova, S.A., Halak, V.I. (2016). Probioticheskaja zashhita slizistyh recipientov kak jetap biotehnologii transplantacii jembrionov krupnogo rogatogo skota. Sbornik statej nauchno-metodich. konf. Stavropol'skoj sel'skohozjajstvennoj akademii. 4, 105-109 (in Russian).

Sidashova, S.O., Avdosieva, I.K., Hryhorasheva, I.M. (2016). Probiotychnyi zakhyst slyzovykh reproduktyvnoho traktu laktuiuchykh koriv. Naukovotekhnich.biul. IBT i DNDKI vetpreparativ i kormovykh dobavok. 5, 112-118 (in Ukrainian).

Sidashova, S.O., Avdosieva, I.K., Hryhorasheva, I.M. (2016). Probiotychnyi zakhyst slyzovykh i molochna 
produktyvnist koriv $\mathrm{V}$ umovakh promyslovoho vyrobnytstva. Nauk.-tekhn. biuleten instytutu biolohii tvaryn ta DNDKI vetpreparativ ta kormovykh dobavok. 17(8), 158-168 (in Ukrainian).

Sidashova, S.O., Humennyi, O.H. (2016). Vplyv probiotynoho zakhystu slyzovykh na funktsiiu yaiechnykiv laktuiuchykh koriv. Naukovyi visnyk veterynarnoi medytsyny: zb.nauk.prats. - bila Tserkva, 2(130), 17-24 (in Ukrainian).

Shilina, Ju., Gushha, N.I., Djachenko, A.I (2008). Jekspressija faktorov patogennosti kak adaptivnaja reakcija u bakterij. Faktori eksperimental'noï evoljuciï organizmiv. Zb.nauk.prac'. K., Logos. 4, 240-246 (in Russian).

Iablonskyi, V.A. (2011). Veterynarne akusherstvo, hinekolohiia ta biotekhnolohiia vidtvorennia tvaryn z osnovamy androlohii. Pidruchnyk. Vinnytsia: Nova knyha (in Ukrainian).
Hill, A. (1965). The environment and disease: association or causation. Proc. R. Soc. Med. 58, 175-195.

Humblot, P. (2001). Use of pregnancy specific proteins and progesterone assays to monitor pregnancy and determine the timing, frequencies and sources of embryonic mortality in ruminants. Theriogenology. 56, 1417-1433.

Kastelic, J. (1991). Spontaneous embryonic death on days 2040 in heifers. Theriogenology. 35, 351-363.

Yong, D., Hassell, T., Duongan, Y. (2002). Chronic factors infections: living with unwanted guests. Nature immunology. 3(11), 1026-1032.

Ran, H., Hasset, D.J., Lau, G.W. (2003). Human targets oh Pseudomonas aeroginosa pyocyanin. Proc. Natl. Acad. Sci. USA. 100(24), 14315-14320.

Received 25.09.2017

Received in revised form 16.10.2017

Accepted 19.10.2017 